\title{
SOME APPARENTLY NEW FORMS OF AFRICAN NYMPHALIDAE.
}

\author{
By LORD ROTHSCHILD, F.R.S., Ph.D.
}

Euphaedra uganda form. viridis form. nov.

o. Differs from typical uganda above in the ground-colour being blackish olive or olive-black, not velvety brown-black, and the blue markings of uganda are replaced by metallic verditer olive-green. A row of submarginal spots on hindwing of similar green also distinguishes this form from uganda, which lacks all submarginal spots.

Below it is marked with yellowish olive-green instead of whitish blue.

Habitat. Entebbe, Uganda, July-August 1900 (Colonel H. B. Rattray), 3 ơ่

Euphaedra luperca ab. suffusa ab. nov.

o. Differs from ab. variegata Aur. in having the whole of fore- and hindwings completely suffused with steel-blue, not only the margins and tornal area.

Habitat. Lake Azingo, Gaboon, December 1907 (Dr. Ansorge), 1 ô.

Euphaedra imperialis Lindemans.

Euphaedra imperialis Lindemans, Tijdsch. Entom. vol. liii. p. 278. pl. 13. f. 1 (1910) (S. Cameroons).

Aurivillius in Seitz suggests that this might prove to be a $\%$ form of luperca Hew., as only 우 were known; the Tring Museum, however, possesses 5 ô $\hat{o}$ and 4 우 of this fine species, and the ô of only differ from the 우우 in being smaller and having the bluish band on the hindwings more sharply defined.

Euphaedra imperialis gabonica subsp. nov.

$\hat{o}$. . Differs from imp. imperialis above in the green suffusion of the wings being much paler, and the orange band of the forewings being much less sharply defined, more diffused and paler.

Habitat. Lambarene, French Congo (Harrington), 1 ô ; 1 ㅇ?

\section{Euphaedra lupercoides sp. nov.}

§. Above forewing velvety black suffused with deep blue; basal one-third irregularly obliquely metallic pale steel-green, an oblique buffish-white band in outer one-third, apical patch white, smaller than in luperca.- Hindwing metallic pale steel-green; abdominal area dull brown, terminal one-fifth of wing steel-blue.

Below olive-green washed with pinkish brown; markings as in luperca, all below vein 2 on forewings cinnamon colour.

Habitat. Luebo, Kassai River, October 1903 (Landbeck), 1 o. 
Euphaedra symphona B. Baker.

Euphaedra symphona Bethune Baker, Ann. Mag. Nat. Hist. (8)2. p. 472 (1908) (Upper Congo).

Both Professor Aurivillius and Dr. Strand place this species in the genus Euryphene. Now Professor Aurivillius in Seitz most emphatically states that there are no structural differences between the two genera Euryphene and Euphaedra, and that the only reliable difference is that in Euryphene the palpi are of various shades of grey, whereas in Euphaedra they are always bright golden or orange-yellow. There are in the Tring Museum 7 ô $\hat{o}$ and 1 of symphona and the palpi of all are deep golden yellow, showing this species to be clearly a Euphaedra. In case it might be supposed that the Tring Museum specimens have been wrongly identified, I would point out that we have also a $\hat{o}$ and $q$ of Euphaedra aurivillii Strand, the only possible species symphona could be confused with.

\section{Euphaedra graueri sp. nov.}

ơ ㅇ․ Ground-colour above deep velvety blue-black.

Forewing basal two-fifths obliquely steel-blue, a postmedian broad oblique orange band consisting of two large quadrate patches joined corner to corner, fringe at apex whitish, and elsewhere black with white intranervular dots.Hindwing basal three-fourths steel-blue.

Below forewing olivaceous grass-green freckled with black scales; 3 black spots in cell, a postdiscal, somewhat dilute black transverse band, oblique transverse orange band paler. Hindwing olivaceous grass-green freckled with black scales; 2 black spots in cell and a black streak on discocellulars, postdiscal band as on forewing, a dark rose-crimson transverse band from costa to beyond vein 3 beyond cell, which curves round and reaches base of wing, the horizontal portion being each side of vein 1, a black line on innerside of the transverse portion of the crimson band.

Length of forewing : ô $39 \mathrm{~mm}$., ㅇ $48 \mathrm{~mm}$. Expanse : ô $83 \mathrm{~mm}$., ㅇ $101 \mathrm{~mm}$.

Habitat. Forest $90 \mathrm{~km}$. west of Lake Albert Edward, February 1908, 1,600 m.

(R. Grauer), 1 ๙ิ, 2 우.

\section{Euphaedra xypete form. albocoerulea form. nov.}

$\hat{o}$ ․ Differs from typical xypete Hew., in the yellow on the upper surface being replaced by bluish white, giving the insect a bluish instead of an olive-green appearance.

Habitat. Same as typical form.

Euphaedra xypete ansorgei subsp. nov.

đㅇ․ Similar to $x$. form. crockeri Butl. but much larger.

Above much less yellow, and in the of the markings less distinct, and in the o the postmedian patch on forewing less round, more quadrate and bandlike.

Below much less yellow, all markings more dilute and less distinct; red on hindwings less distinct and more washed out.

Length of forewing f. crockeri ô $31-41 \mathrm{~mm}$., क + 42-45 mm.

Expanse „, „ „ ô $66-86 \mathrm{~mm}$., 우 $89-95 \mathrm{~mm}$. 
Length of forewing $x$. ansorgei ô 41-48 mm., 우 49-53 mm.

Expanse ,", of $87-101 \mathrm{~mm}$., ㅇ 103-111 mm.

Habitat. Lake Asebbe, Fernan-Vas, Gaboon, February 1908 (Dr. Ansorge), 28 ô $\hat{o}, 9$ 우 ; Kassai River, Congo Free State, 3 ôô.

Euphaedra gausape landbecki subsp. nov.

o. Differs from g. gausape Butler above in the oblique band of forewing merging more into the ground-colour and being much greener, also green of hindwing is much more saturated with yellow.

ㅇ. Differs in the green portions of both wings being suffused with yellow and the oblique band with green.

Habitat. Luebo, Kassai River (P. Landbeck), 4 ô ô, 2 웅․

\section{Euphaedra cyparissa aureola subsp. nov.}

$\hat{o}$.. Differs from $c$. cyparissa in the green areas of both wings being strongly suffused with yellow.

Habitat. Luebo, Kassai River (P. Landbeck), 1 ô, 1 ㅇ ; 1 ㅇ, Kassai River, Congo Free State.

\section{Euphaedra difficilis sp. nov.}

\section{o. Allied to inanum Butl.}

Forewing above basal half obliquely dirty olive wood-brown, basal area darker brown; outer half black, a postmedian oblique white band, fringe black, white at apex and with intranervular white dots.- Hindwing dirty umberbrown; a $3 \mathrm{~mm}$. wide terminal band greyish black, with an inner row of grey oblong spots, inside which is a band of big velvety black lunules.

Below both wings brown-grey; on forewing 2 black spots in cell and white oblique postmedian band, hindwing a lavender-grey patch at base, a submarginal row of grey spots and a greyish postmedian shade.

Length of forewing: $41 \mathrm{~mm}$. Expanse: $87 \mathrm{~mm}$.

Habitat. Mori River, Kosowa (F. R. Roberts), 1 ô.

Euphaedra preussi form. cinnamomea form. nov.

o. Has above all the green areas cinnamon colour washed with blue, and a large patch of blue above tornal area of hindwing.

Habitat. Kongour Forest, Manyema, Congo Free State (R. Grauer), 1 ô.

Euphaedra preussi form. castanea form. nov.

․ All green areas above replaced by rufous chestnut saturated and suffused with purple-blue, tornal area of hindwing and a submarginal row of spots blue. On forewing 3 black spots in cell above.

Habitat. Kongour Forest, Manyema, Congo Free State (R. Grauer), 1 우.

Aterica galene omissa subsp. nov.

o. Differs above from $g$. theophane Hopfi by the spots of the postmedian oblique band being much smaller, rounder, and all widely separated and by the absence of all rufous on the cream-coloured central patch of the hindwings. 
o. Differs in the white spots on forewing being smaller, and in the central area of hindwings being smaller and white, not rufous.

Habitat. Chaipaika Estate, Bandawe, Nyassaland (Watkinson), 3 ô ô ; Parambira, Lake Nyassa, November 1893 (Dr. Ansorge), 3 ồ , 1 q.

\section{Catuna crithea pallidior subsp. nov.}

o + . Differs above from c. crithea Drury, in the pale markings of the forewings being greyish white, not grey-brown or yellowish wood-grey, and the buffish yellow of the hindwings is replaced by cream-white.

Habitat. Bitje, Ja River, Cameroons, 2,000 ft., January-March, AprilJune, and October-November 1907-1910 (G. L. Bates), 9 ô ô, 7 웅․

It may be urged that this is only an aberration as there are typical crithea in the Tring Museum labelled Cameroons, but these are from a most unreliable source and almost certainly from Acera, Gold Coast.

\section{Catuna angustata albidior subsp. nov.}

$o f$. This form shows the same differences from $a$. angustata Feld. as the previous form does from $c$. crithea, viz. all grey and yellow areas replaced by creamy white. A. angustata occurs in the Gaboon and Congo, while a. pallidior occurs from the Ivory Coast to Nigeria and Cameroons. In the Tring Museum are 29 ô ô, 11 우 from Bingerville, Ivory Coast, June 1915 (G. Melou); Gold Coast; Bitje, Ja River, Cameroons, 2,000 ft. (G. L. Bates); Ushire, Niger Coast Protectorate, January 1902 (Dr. Ansorge); Warri, Niger, May-September 1897 (Dr. Roth).

Neptis comorarum leighi subsp. nov.

$\hat{o}$ ㅇ. Differs from $c$. comorarum in being much smaller and in the orange spots above being paler and the markings below much less distinct and sharp.

Length of forewing: c. comorarum of $26 \mathrm{~mm}$. ㅇ $30 \mathrm{~mm}$.

Expanse " ,, of $55 \mathrm{~mm}$., 우 $64 \mathrm{~mm}$.

Length of forewing: c. leighi ô $21 \mathrm{~mm}$., 우 $24 \mathrm{~mm}$.

Expanse ,, , की $45 \mathrm{~mm}$., ㅇ $51 \mathrm{~mm}$.

Habitat: Anjouan Island, Comoro Islands, July 1911 (G. F. Leigh).

(Habitat of $c$. comorarum, Grande Comore, Comoro Islands).

Neptis ochracea parvimacula subsp. nov.

$\hat{o}$ ‥ Differ above from $o$. ochracea Neave in all the yellow markings being much darker, in the patches on the forewings on each side of veins 1 and 3 being much smaller, and in the band of the hindwing being much narrower.

Habitat. Kwidgwi Island, Lake Kivu, 1,500-2,000 m. $=4,875-6,500 \mathrm{ft}$. November 1907 (R. Grauer), 1 ô, 1 ㅇ․

Neptis exaleuca suffusa subsp. nov.

o. Differs above in the ground-colour being much blacker, and in the white patches on each side of veins 1 -and 3 of the forewings being much smaller. Below it is strongly washed with rufous orange isstead of greenish yellow.

Habitat. Forest $95 \mathrm{~km}$. west of Lake Albert Edward, 1,000 m. $=3,250 \mathrm{ft}$., . February 1908 (R. Grauer), 1 ô. 
Neptis neavei sp. nov.

ô. Ground-colour sooty black without any traces of darker intranervular streaks as in exaleuca; forewing with 2 white dots in cell and 3 beyond it, remainder of white markings as in exaleuca but the patches on each side of vein 3 more oval, and those on each side of vein 1 very small; on the hindwing the white band only reaches to vein 6 . Below forewing as above but basal half of costal and subcostal area rufous chestnut; hindwing rufous chestnut, white band has above vein 6 a round white dot, white band bordered each side with heavy black line, terminal margin black.

Length of forewing: $27 \mathrm{~mm}$. Expanse : $58 \mathrm{~mm}$.

Habitat. Mlanje, Nyassaland, May 1913, 1 ô.

\section{Neptis incongrua occidentalis subsp. nov.}

o. Ground-colour greyer than in inc. incongrua. Differs on forewing by all the spots in the postmedian white band being wanting except those on each side of veins 1,3 , and 6 and these are much smaller. The band on the hindwing is narrower. Both above and below it also differs in having intranervular darker streaks. Below the disc of forewing and outer fifth of hindwing are much deeper rufous.

Habitat. Forest $90 \mathrm{~km}$. west of Lake Albert Edward, 1,000 metres $=3,250$ ft., February 1908 (R. Grauer), 1 ô.

\section{Crenis pechueli rhodesiana subsp. nov.}

$\hat{o}$ ㅇ. Above much bluer less lavender-coloured than $p$. pechueli Dew. Differs below in the brighter orange less rufous forewing and in the narrower orange bands encircling the postmedian row of black spots on the hindwings.

Habitat. Fort Rosebery, Rhodesia, 2 ô ô.

Crenis boisduvalii omissa subsp. nov.

Professor Aurivillius makes boisduvalii occur from Sierra Leone to Angola and Natal, and from the Congo to East Africa; but the Natal of are much less rufous and the ô ô generally smaller. Below the Natal specimens are much duller and the markings less distinct.

In the Tring Museum are the following specimens:

C. b. boisduvalii, 57 ô ô, 44 우 Natal, Cape Colony, Pondoland, Transvaal and Delagoa Bay.

C. b. omissa, 46 ồ ô $^{7}$ 우, Angola, Congo, Cameroons, Toro, Unyoro, and Uganda.

Crenis trimenii angolensis subsp. nov.

$\hat{o}$ ㅇ. Differ from $t$. trimenii Aur. in being much paler and much brighter yellow.

Habitat. Fort Quilenges, Benguella, January 1905 (Dr. Ansorge), 1 ô; Combo Coquenje Bihé, Angola, October 1904 (Dr. Ansorge), 1 đ̃; Bigondo Bihé, Angola, October 1904 (Dr. Ansorge), 4 우; North Bailundu, Angola, September 1901 (Pemberton), 9 ô ô, 1 우; Bihé, Angola (Pemberton), 1 ô, 2 우․ 
Crenis trimenii major subsp. nov. colour.

ơ ㅇ․ Differs from $t$. trimenii Aur. by its much larger size and more yellow

Length of forewing: $t$. trimenii of $25 \mathrm{~mm}$., 우 $29 \mathrm{~mm}$.

Expanse ," , , of $53 \mathrm{~mm}$., 우 $62 \mathrm{~mm}$.

Length of forewing: $t$. major ô $53 \mathrm{~mm}$., 우 $36 \mathrm{~mm}$.

Expanse ", , , o $70 \mathrm{~mm}$., 우 $77 \mathrm{~mm}$.

Habitat. Bitje, Ja River, Cameroons, 2,000 ft., April-May and OctoberNovember 1910 (G. L. Bates), 5 ô ô, 4 우우; Stanley Pool to Lokolele, Congo River, 1894 (Harrison), 1 ô, 1 f ; Luebo, Kassai River, October 1903 (Landbeck), 1 ㅅ, 7 우; Luluaburg, Kassai (Landbeck), 1 ô; Kapulumbo, Kassai (Landbeck), 3 우; Kassai River, 1 ơ, 2 우.

Mesoxantha ethosia albeola subsp. nov.

o. Differs from e. ethosia Drury in the yellow between veins 1,2 , and 3 of the forewings extending nearer to termen and in the black terminal band of the hindwings being narrower. + . Differs in the pale colour of the forewing being white, the terminal band of hindwing being narrower, and the yellow of hindwing paler and more buffish.

Habitat. Cameroons, West Africa, 1 ô ; Bitje, Ja River, Cameroons, 2,000 ft., A pril-June and September-October 1910 (G. L. Bates), 2 ô $\hat{0}, 6$ 우; Lake Azingo, Gaboon, December 1907 (Dr. Ansorge), 1 o ; Lake Asebbe, Fernan-Vas, Gaboon, February 1908 (Dr. Ansorge), 4 ô $\hat{o}, 2$ 우; Abanga River, Gaboon October 1907 (Dr. Ansorge), 1 ô, 8 우; Ogowe River (Distant Coll.), 1 ; ; 10 and 15 days from Fort Beni, Congo, May 1899 (Dr. Ansorge), 2 우 ; 1 ô Luebo, Kassai River (P. Landbeck), 1 ô; Gallery Forest, Rutschuru River, 1,000 m. $=3,250$ ft., February 1908 (R. Grauer), 1 ô.

\section{Mesoxantha ethosia reducta subsp. nov.}

․ Differs in having the white on forewing much reduced.

Habitat. Port Alice, February 1897 (Dr. Ansorge), 1 ô ; Kampala, Uganda, January 1897 (Dr. Ansorge), 2 ô ô, 2 우; Entebbe, Uganda, April 1900 (Colonel H. B. Rattray), 4 oิ ô; Monyonyo, Unyoro, March 1897 (Dr. Ansorge), 2 ơ ô, 2 우; Delagoa Bay (Mrs. Monteiro), 1 ô.

\section{Hypolimnas salmacis magnifica subsp. nov.}

๙. Differs in being much larger and the white bands on both wings much wider and more extended.

. Much larger, the white bands of both wings much wider and more extended; the blue paler and more turquoise, less purple.

Length of forewing: s. salmacis of $48 \mathrm{~mm}$., ㅇ $52 \mathrm{~mm}$.

Expanse ", , , o $101 \mathrm{~mm}$., ㅇ $109 \mathrm{~mm}$.

Length of forewing: s. magnifica ơ $53 \mathrm{~mm}$., 우 $63 \mathrm{~mm}$.

Expanse , , , ô $111 \mathrm{~mm}$., † $132 \mathrm{~mm}$.

Habitat. Port Alice, July 1894-January 1897 (Dr. Ansorge), 1 of, 1 ㅇ ; Entebbe, Uganda, May-July 1900-1902 (Col. H. B. Rattray), 5 ơồ, 5 우. 


\section{Hypolimnas monteironis major subsp. nov.}

- 0 . Larger, and the white bands of both wings broader. The $q$ has the hindwing distad of white band more rufous.

Length of forewing: $m$. monteironis of $48 \mathrm{~mm}$., ㅇ $50 \mathrm{~mm}$.

Expanse ", ,, , o $101 \mathrm{~mm}$. , ㅇ $105 \mathrm{~mm}$.

Length of forewing: $m$. major of $55 \mathrm{~mm}$., ㅇ $62 \mathrm{~mm}$.

Expanse , , , , ô $116 \mathrm{~mm}$., ㅇ $130 \mathrm{~mm}$.

Habitat. Port Alice, January 1897 (Dr. Ansorge), 3 oิ ô, 3 우 ; Entebbe, Uganda, 3 ơơ ; Entebbe, Uganda, April-June, 1900-1902 (Colonel H. B. Rattray).

\section{Hypolimnas dinarcha grandis subsp. nov.}

of . Larger than $d$. dinarcha Hew., and the pale patch on hindwing larger and more sharply defined.

Length of forewing: d. dinarcha o $50 \mathrm{~mm}$., $q 54 \mathrm{~mm}$.

Expanse ,, ,, , ô $105 \mathrm{~mm}$., \& $114 \mathrm{~mm}$.

Length of forewing: d. grandis ô $57 \mathrm{~mm}$., ㅇ $62 \mathrm{~mm}$.

Expanse , , , ơ $120 \mathrm{~mm}$., ㅇ $130 \mathrm{~mm}$.

Habitat. Port Alice, January-July 1894-1897 (Dr. Ansorge), 2 oิ ô, 2 우; Msarosaro, Uganda, March 1896 (Dr. Ansorge), 2 ôे, Entebbe, Uganda, April 1900 -August 1902 (Colonel H. B. Rattray), 9 ơ ô, 2 우; Hoima, Unyoro, October 1897 (Dr. Ansorge), 1 ơ ; Measa, Usogo, March 1898 (Dr. Ansorge), 1 우.

\section{Hypolimnas dubius poensis subsp. nov.}

․ Differs from $d$. dubius in the enormous size of the white patch in cell and those on each side of vein 3 and in the deep rufous pale area of hindwing and in the presence of 3 white submarginal dots only on hindwing.

Habitat. Banterberri, Fernando Po (E. Seimund), 1 \%.

\section{Hypolimnas dubius mayottensis subsp. nov.}

o. Similar to $d$. drucei Butl. but much larger ; the white patches on forewings very much larger and the white of the hindwings extending much closer to termen than in $d$. drucei ab. bewsheri Butl.

ㅇ. Very much larger than $d$. drucei and the white much more extended, in two specimens being spread almost over the dise of both wings.

Length of forewing: d. drucei ot $38 \mathrm{~mm}$., o $45 \mathrm{~mm}$.

Expanse ", , , ơ $80 \mathrm{~mm}$., 우 $95 \mathrm{~mm}$.

Length of forewing: $d$. mayottensis of $44 \mathrm{~mm}$., 우 $53 \mathrm{~mm}$.

Expanse , ,, , ô $93 \mathrm{~mm}$., ㅇ $112 \mathrm{~mm}$.

Habitat. Mayotte, Comoro Islands, May 1911 (G. F. Leigh).

Catacroptera cloanthe intermedia subsp. nov.

9. Form. pluv. Exactly intermediate between c. cloanthe f. pl. cloanthe and c. ligata R. and J. f. pl. ligata.

Habitat. Luebo, Kassai, October 1903 (P. Landbeck), 1 \&; Mazanguli, Lualaba Valley, 2,000 ft., 1 \& (type). 
Precis natalica form. arid. natalensis form. nov.

$\hat{o}$ ㅇ. Distinguished from f. pl. natalica Feld. by the washed-out patternless underside.

Precis natalica angolensis subsp. nov.

o + . Diffèr from $n$. natalica in the paler grey ground-colour and the almost complete absence of red markings on upperside. Dry season form $n$. angolensis form. arid. penricei form. nov. differs in the same way from $n$. angolensis $\mathrm{f}$. $\mathrm{pl}$. angolensis as f. arid. natalensis does from f. pl. natalica.

Habitat. Ndaila Ango, Angola, October 1903 (Dr. Ansorge), 1 ô, f. pl. angolensis ; Kuvali River, Angola, January 1899 (Penrice), 6 ồ ô, f. pl. angolensis ; Cubal River, Angola, February 1899 (Penrice), 3 ô ô, f. pl. angolensis, 2 ô ô, 2 우워 f. ar. penricei; Dondo, Melanga, and Pungo Andongo, Angola, March-July 1875 (Major v. Homeyer), $1 \hat{o}, 1$ ㅇf. pl. angolensis, 1 우 1 ô f. arid. penricei ; Pungo Andongo, Angola (Dr. Ansorge) 1 f f. ar. penricei; N. Bailundu, Angola, 1901 (Pemberton), 1 ô f. ar. penricei; Duque de Braganza, Angola (Dr. Ansorge), 1 ô f. ar. penricei; Cailulu, Angola (Pemberton), 1 ô, f. ar. penricei; Benguella to Caconda and 80 miles into interior, May-June 1897 (Penrice), 4 ôे, 4 우 f. arid. penricei; Calweba River, Angola, May 1898 (Penrice), 1 ô, 1 우, f. ar. penricei; Lukia River, Angola, April 1899 (Penrice), 1 ô f. ar. penricei; Libollo, Angola (Pemberton), 1 ô, f. ar. penricei.

Precis archesia f. arid. extr. loc. coryndoni form. nov.

$\hat{o}$ ․ Differ above on the forewing from f. arid. archesia Cram. and by the almost complete absence of red, and the blue is much more sky blue, not purplish ; the blue forms a broad marginal band with a central black line, not two broken blue submarginal lines; the whole postmedian band is blue, not merely above vein 4 . On the hindwings the median band is duller and less distinct, and the terminal edge is quite straight, not strongly erenulate; the fringe is blue, not white. Below it is even more extreme and patternless than the form. arid. ampl. staudingeri Dew.

Habitat. Various parts of Angola 13 ô ô, 4 우우 (Coryndon).

\section{Precis omissa sp. nov.}

o. This species is allied to milonia Feld. and ranana Gr. Smith and is in many collections named ranana in error. Differs above from milonia by the forewing being more produced at the apex, and by the rufous band being more angled basad, and stopping short at vein 6 . The hindwing has a longer tail, is more bowed out at termen and the fulvous rufous band is narrower. The white dot in apical area of forewing is absent.

․ Is duller and has the fulvous band on hindwing almost white.

Length of forewing: ô $30 \mathrm{~mm}$., o $33 \mathrm{~mm}$. Expanse : of $64 \mathrm{~mm}$., o $71 \mathrm{~mm}$.

Habitat. Bitje, Ja River, Cameroons, 2,000 ft., January-March and September-November 1907 (G. L. Bates), $6 \hat{o} \hat{o}, 6$ 우; interior of Cameroons 1 ㅇ Luebo, Kassai River (Landbeck), 1 ; ; 2 days from Fort Beni, Congo Free State, May 1899 (Dr. Ansorge), 1 ㅇ. 


\section{$2 \mathrm{BHL}$ Biodiversity Heritage Library}

1918. "Some apparently new forms of African Nymphalidae." Novitates zoologicae : a journal of zoology in connection with the Tring Museum 25, 338-345. https://doi.org/10.5962/bhl.part.29770.

View This Item Online: https://www.biodiversitylibrary.org/item/24178

DOI: https://doi.org/10.5962/bhl.part.29770

Permalink: https://www.biodiversitylibrary.org/partpdf/29770

\section{Holding Institution}

Natural History Museum Library, London

\section{Sponsored by}

Natural History Museum Library, London

\section{Copyright \& Reuse}

Copyright Status: Public domain. The BHL considers that this work is no longer under copyright protection.

This document was created from content at the Biodiversity Heritage Library, the world's largest open access digital library for biodiversity literature and archives. Visit BHL at https://www.biodiversitylibrary.org. 